\title{
AN IRISH NATIONALIST PERSPECTIVE ON EASTERN EUROPE WILLIAM SMITH O'BRIEN'S TRAVEL JOURNALS, 1861-1864
}

\begin{abstract}
The travel journals of Irish nationalist politician William Smith O'Brien, challenge the claim by Larry Wolff of a general western European condescension towards eastern Europe from the eighteenth century onwards. Hostility towards British rule in Ireland led Smith O'Brien to celebrate and identify with the Hungarians and Poles in their struggles against their imperial rulers during his travels in the 1860s. He concluded, however, that the Irish suffered more under Britain than these nations under either Austria or Russia.
\end{abstract}

Key words: Ireland, Poland, Hungary, Nationalism, Travel-Writing, Orientalism

Słowa kluczowe: Irlandia, Polska, Węgry, nacjonalizm, literatura podróżnicza, orientalizm

The Irish nationalist politician, William Smith O’Brien marked his passage from Vienna to Pest in a fashion as dramatic as any of the eighteenth-century predecessors described by Larry Wolff in his hugely influential study, Inventing Eastern Europe. ${ }^{1}$ He began his journal entry for $15^{\text {th }}$ August 1861 with the following exclamation: "Here I am! safely arrived in the capital of Hungary." His expression of relief suggested an arduous and dangerous journey. It had, in fact, been nothing of the sort - Smith O'Brien had travelled by boat from Ireland to England and then to France, spent a pleasant week in Paris, before travelling on by train to Vienna, with brief stopovers to see the sights of Strasbourg, Baden-Baden, Munich and Salzburg. From Vienna he boarded a small steamer and switched to a larger

Larry Wolff, Inventing Eastern Europe: The Map of Civilization on the Mind of the Enlightenment (Stanford: Stanford U.P., 1994). 
one once on the Danube proper. He passed the trip to Pest learning about the affairs of Hungary from fellow-passengers and surveying the scenery on the river banks. In fact, he judged the day "as one of the most agreeable" that he had spent since leaving Ireland. ${ }^{2}$

His sense of relief on reaching Pest might be read as an internalisation of the image of eastern Europe as remote and forbidding promoted by Wolff's travellers from western Europe. Smith O'Brien was not simply travelling from one European city to another but, according to Wolff's claims, crossing the border between western and eastern Europe. In fact, of all travellers from western Europe, he had come the furthest to experience eastern Europe. $\mathrm{He}$ lived on the estate of Cahirmoyle, County Limerick, on the western seaboard of the western periphery of Europe. The entries from Hungary and later Poland in his travel journal of 1861 confirm that Smith O'Brien grasped the significance of his arrival in Pest. These located Hungary firmly in eastern Europe. In an entry written in Füred, he talked of the ignorance of Hungarian wines in western Europe and compared the appearance of Hungarians and the inhabitants of western Europe, as if to suggest that all the nationalities of the west were bound by a common ethnic background that ended at the Hungarian border. ${ }^{3}$ Indeed his very itinerary in 1861 reflected the new conceptual geography of the early modern period, which had re-imagined Europe on an East/West rather than North/South axis and thus detached Poland from its northern neighbours. ${ }^{4}$ His tour followed a west-east trajectory taking him no further north than Galicia, the name given to the Polish partition under Habsburg control, and no further south than Slovenia, also a territory of the Austrian Empire.

Much like earlier travellers, too, Smith O'Brien experienced the linguistic diversity of eastern Europe as unsettling. After a month in eastern Europe he complained: "My mind is in a sad state of confusion with regard to languages. I can understand with more or less facility eight languages. English, Irish, Latin, Greek (ancient \& modern), Italian, German, Spanish and French when I read them, but I can speak with fluency only two, English and French." Lacking knowledge of Magyar or any Slavic language, he was obliged to converse with locals, depending on their abilities, in English, French or even Latin. In an earlier entry he revealed that his linguistic limitations were not simply confusing, but also alienating. One of the horses pulling his carriage fell ill while travelling at night over the Carpathians and the driver went to seek help. Left alone with just the remaining horse for company, Smith O’Brien felt his position "embarrassing." His ignorance of eastern European languages and the darkness of the night sharpened his sense of being out of place and made him feel vulnerable: "Alone, in darkness and under rain I began to reflect that the

2 William Smith O'Brien, Journal of an Excursion made during the months of August and September 1861 (National Library of Ireland, MS 32,707. MS 714 and MS 718 in the same collection appear to be an earlier version of the text. Pest, 15 Aug. 1861).

3 Smith O’Brien, MS 32,707 (Füred, 19 Aug. 1861).

4 Wolff, Inventing Eastern Europe, op. cit., 144-94.

5 Smith O’Brien, MS 32,707 (Laibach, 13 Sept. 1861). 
first waggoner who might pass me would find me in what is called 'a false position' for I was unable to see my hand and I could not speak a single word of the Slovack language used by the peasantry in this neighbourhood." Like his journey to Pest, his story ended with a sense of relief: "After remaining in this embarrassing position for nearly half an hour I was at length released by the appearance of my companion." ${ }^{\circ}$ His unfamiliarity with Magyar also meant that he was unable to experience release in a more positive sense - that provided by comedy. He spent an hour watching a Hungarian comedy in Debrecen, but was so bewildered by the language that he could not even describe the action. ${ }^{7}$

In other respects, however, Smith O'Brien departed from the condescension towards eastern Europe displayed by many western travellers, even to the point of suggesting that eastern Europe could provide instruction to the west. His travel journals demonstrate that there was no one homogenous view of eastern Europe in western Europe, as Wolff implied in his 1994 study. Rather, as Maria Todorova has argued: "Everyone has had one’s own Orient, pertaining to space or time, most often to both. The perception of the Orient has been, therefore, relational, depending on the normative value set and the observation point." ${ }^{\prime}$ As an Irish nationalist, Smith O'Brien brought a perspective to eastern Europe that was quite different from other western European travellers, including those from Britain with which Ireland was politically joined. ${ }^{9}$ Although his family were Protestant and belonged to the landlord class, they were descendants of the famous native Irish king, Brian Boru, rather than the English and Scottish settlers who had come in the sixteenth and seventeenth centuries as part of a campaign to consolidate English rule in Ireland. His family were consistent critics of anti-Catholic laws designed to coerce the native population into accepting the Reformation, and his own father had voted against the dissolution of the Irish parliament in Dublin in the Act of Union of 1801. Elected to Westminster in 1828, Smith O'Brien campaigned for reforms in British policy in Ireland to alleviate the sufferings of the Irish peasant and for the repeal of the Union and thus the return of self-government to Ireland. He aligned himself with the popular Catholic leader, Daniel O'Connell, and also joined the Young Ireland movement, which sought to promote awareness of the uniqueness of Ireland's culture as a stepping stone to eventual self-government, but also organised a rebellion in 1848 to achieve independence by force. ${ }^{10}$

\footnotetext{
Smith O'Brien, MS 32,707 (Cracow, 9 Sept. 1861).

Smith O’Brien, MS 32,707 (Hotkocz, 3 Sept. 1861).

8 Maria Todorova, Imagining the Balkans (Oxford: Oxford U.P., 1997), 12.

9 On Irish attitudes to Poland generally, see Róisín Healy, Poland in the Irish Nationalist Imagination, 1772-1922: Anti-Colonialism within Europe (London: Palgrave, 2017).

10 Recent biographies of Smith O'Brien include Richard Davis, Revolutionary Imperialist: William Smith O'Brien, 1803-1864 (Dublin: Lilliput, 1998); Robert Sloan, William Smith O'Brien and the Young Ireland Rebellion of 1848 (Dublin: Four Courts Press, 2000); and Blanche M. Touhill, William Smith O'Brien and his Irish revolutionary companions in penal exile (Columbia: Univ. of Missouri Press, 1981).
} 
This background translated into a sympathetic attitude to eastern Europe. Coming from a country that British colonists had described as backward and irrational, Irish nationalists were sensitive to constructions of subject peoples as unworthy of self-government. ${ }^{11}$ When the organ of the Young Irelanders, The Nation, described the Austrian Empire as straddling western civilisation and eastern barbarism, it put barbarism in inverted commas. ${ }^{12}$ Irish nationalists were interested in eastern Europe only, however, insofar as it could be deployed for their own purposes. They were especially drawn to Hungary and Poland because they saw them as historic nations unjustly reduced to colonial status and thus parallels to Ireland. By emphasising the similarities between the plight of Ireland and these others, they hoped to gain a share in the international sympathy lavished on these nations as victims of Great Power domination. In turn, they might expose the hypocrisy of the British government, for condemning in eastern Europe the same repressive policies that they apparently applied in Ireland. ${ }^{13}$ British radicals and even some liberals adopted this strategy towards eastern Europe too. They contrasted in particular expressions of sympathy for the subject nations of eastern Europe with government reluctance to intervene on their behalf. ${ }^{14}$ The involvement of controversial figures such as the Chartists and Karl Marx, as well as Irish nationalists, in the Polish cause, however, caused the bulk of British observers to become more wary of Polish nationalism. ${ }^{15}$ If sympathy for the Hungarian cause was greater, there was also a perception in Britain that the Hungarians had gone too far in their efforts to resist the Austrians by force in $1848-49 .{ }^{16}$

From the late eighteenth century onwards Irish nationalists alternated between Hungary and Poland in their search for models for Ireland. Political developments in both Ireland and eastern Europe determined the relative popularity of each. The events of the French revolutionary era brought Poland to the fore as an eastern European equivalent to Ireland. Theobald Wolfe Tone, the founder of the republican association, the United Irishmen, was the first prominent Irishman to identify a link between Ireland and Poland. On trial for treason for leading the 1798 Rising against British rule, he compared himself with the patriot,

11 Emblematic of this view is the early modern text, Edmund Spenser, $A$ View of the Present State of Ireland (1596).

12 'Austria and Hungary', The Nation (23 Feb. 1861).

13 On Irish attitudes to eastern Europe generally, see Róisín Healy, 'Inventing Eastern Europe in Ireland, 1848-1918, The Yearbook of the "Gheorghe Şincai" Institute for Social Sciences and the Humanities of the Romanian Academy, XII (2009), 103-17, [http://www.icsumures.acad-cluj.ro/anuare/abstracts\%202009. pdf, accessed 12 September 2017].

14 See Alan John Percivale Taylor, The Troublemakers: Dissent over Foreign Policy 1792-1939, $2^{\text {nd }}$ ed. (London: Pimlico, 1993).

15 Thomas McLean, The Other East and Nineteenth-Century British Literature: Imagining Poland and the Russian Empire (London: Palgrave, 2012), 116-17.

16 Tibor Frank, Picturing Austria-Hungary: the British Perception of the Habsburg Monarchy 1865-1870 (Boulder, Col.: Social Science Monographs, 2005), 9-10, 129. 
Tadeusz Kościuszko. Although they had failed to win the freedom of their countries from foreign oppressors, he claimed their cause was equally noble. ${ }^{17}$ Opponents of the Act of Union, passed in response to the Rising, compared the closure of the Dublin parliament and the end of legislative independence for Ireland with the recent partitions of Poland. ${ }^{18}$ Irish nationalists were unimpressed with the Peace of Vienna of 1815 and condemned the partitioning powers for their greed in seizing Poland and their repressive policies towards it. Here too they saw similarities with Britain's treatment of Ireland. In 1848 the Confederate Clubs, an offshoot of the Young Irelanders, spoke of Ireland, Poland and Italy as "the long-oppressed nations of Europe". ${ }^{19}$ Hungary was already, however, replacing Poland as the preferred parallel for Ireland. The long-sustained success of the Hungarians in their rebellion against Austrian rule gave Irish nationalists hope that they too could throw off British rule, and the brutal suppression of the rebellion with Russian assistance confirmed their worst fears about Austria. The nationalist organ, the Freeman's Journal, likened the closure of Hungary's parliament in Pest in 1849 to that of the Irish parliament in $1801 .^{20}$ The aftermath of the rebellion also brought Hungary into a situation reminiscent of Ireland after the Young Ireland Rebellion of 1848. John Mitchel, the most vitriolic Irish critic of British rule, wrote in his Jail Journal, published in 1854, of the similarities between the two nations, pointing in particular to the exile of its leaders, and reserved special mention for Lajos Kossuth. ${ }^{21}$ The claim that the Polish patriot and writer, Adam Mickiewicz, had the book by his bedside when he died the following year suggests that the perception of a common Irish and eastern European fate was not confined to Irish nationalists. ${ }^{22}$

17 Marianne Elliott, Wolfe Tone: Prophet of Irish Independence (New Haven: Yale U.P., 1989), 393. Elliott used the version of the speech in copies of the original found in Dublin Castle. Later versions made Tone appear more confrontational.

18 Francis Hardy made this point in the Irish House of Commons, A report of the debate in the House of Com-

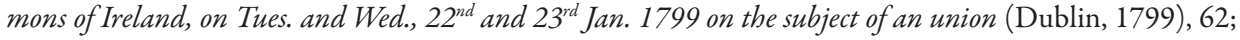
Capel Molyneux, A reply to the memoire of Theobald McKenna, Esq. On some questions touching the projected union of Great Britain and Ireland (Dublin: H. Fitzpatrick, 1799), 36.

19 Davis, Revolutionary Imperialist, op. cit., 239.

20 William O'Reilly and Andrea Penz, Freiheit und Unabbängigkeit als imperative Postulate: Nationale Bewgung in Irland und Ungarn im Vergleich (1780-1870) (Graz: Leykam Verlag, 2006), 18, 91; Freeman's Journal (26 May 1860).

21 Thomas Kadebo, Ireland and Hungary: A study in parallels with an Arthur Griffith bibliography (Dublin: Four Courts Press, 2001), 23-24.

22 Adam Mickiewicz, transl. Liam Ó Rinn, Leabhar na Pólainne (Dublin: An Comhlucht Éireannach um Thráchtáil Eadarnáisiúnta, 1922), xiii.Jail Journal or Five Years in British Prisons was written while Mitchel was in exile after 1848 in Van Diemen's Land or Tasmania, from which he escaped in 1853, and published by the offices of the 'Citizen' in New York in 1854. On Polish perceptions of commonality, see Eoin MacWhite, 'Thomas Moore and Poland', Proceedings of the Royal Irish Academy 72 (Dublin: RIA, 1972), 49-62, and for a later period, John A. Merchant, The Impact of Irish-Ireland on Young Poland, 1890-1919 (Boulder: Columbia U.P., 2008). 
If there was considerable Irish interest in eastern Europe, Smith O'Brien was exceptional in taking the trouble to visit the region. While Irish nationalists were remarkably well travelled-many spent time in France, America, and Australia, not to mention the vast territories of the British Empire-few ventured east of Germany. Indeed there are relatively few first-hand accounts by Irish travellers of either nationalist or Unionist persuasion to anywhere in eastern Europe in the nineteenth century. Zsusanna Zarka has identified two Irishmen who availed of the steamboat service opened up on the Danube in 1831 to explore Hungary, the former diplomat, Lord Londonderry, and the nationalist journalist, Michael Joseph Quin. ${ }^{23} \mathrm{~A}$ former soldier in the British army, James Creagh from County Clare later wrote an account of the Balkans in $1875 .{ }^{24}$ Of all those who recorded their impressions of eastern Europe, the journalist, John David Bourchier, like Smith O'Brien from County Limerick, spent most time in eastern Europe, living in various locations in the Balkans from 1888 to 1920 . He reported on his experiences in several publications, including the Times of London. ${ }^{25}$

Smith O'Brien made up for the paucity of Irish visitors to eastern Europe with his enthusiasm for the region. He visited eastern Europe three times in all, in 1843, when he briefly ventured from Germany to Pressburg (Bratislava), in 1861, when he conducted a month-long tour of the Habsburg Monarchy, and finally in 1862-63, when he spent over six months travelling the length and breadth of eastern Europe, from the Mediterranean to the Baltic Sea. On the final trip, he visited Greece, Constantinople, Bucharest, Vienna, and Warsaw, but also towns deep in the western gubernii of Russia, Grodno (Hrodno), Wilna (Vilnius) and Kovno (Kaunas). He had a keen interest in different cultures and was undaunted by the prospect of travelling beyond the usual confines of English or Irish travellers to the continent. He was even so bold as to travel to Grodno in the midst of the Polish Uprising of 1863 , when insurgents were derailing and shooting at trains. In this sense, he was thus fully justified in his fear of what awaited him to the east: "Behold me then again hurtling eastwards into a region in which danger at present awaits the traveller

23 Charles William Stuart Vane, Marquess of Londonderry, A steam voyage to Constantinople by the Rhine and the Danube in 1840-41 (London, 1842); Michael Joseph Quin, A steam voyage down the Danube: with Sketches of Hungary, Wallachia, Servia and Turkey (London, 1835). Zsuzsanna Zarka, 'A dunai gözhajózás, mint a fejlődés motorja. Ír benyomások a Habsburg Birodalomról és Magyarországról a 19. század kőzepén', Idegen szemmel. Magyarságkép 19.-20. századi útlírásokban, ed. Árpád Hornyák, Vitári Zsolt (Budapest: Szerkesztők, 2010), 31-49.

24 James Creagh, Over the borders of Christendom and Eslamiah: A Journey through Hungary, Slavonia, Serbia, Bosnia, Herzegovina, Dalmatia, and Montenegro, to the North of Albania in the Summer of 1875 (London: Tinsley, 1876). See Neval Berber, 'The Irish Paradigm in the $19^{\text {th }}$ Century British Discourse on Bosnia-Herzegovina,', Imagining Frontiers: Contesting Identities, ed. Steven Ellis and Ludá Klusákova (Pisa: Pisa U.P., 2007), 319-338.

25 Michael Foley, 'John David Bourchier: an Irish Journalist in the Balkans', Irish Communications Review, $10 / 1(2007)$. 
at every step." ${ }^{26}$ Indeed he had travelled much further in earlier years, if not of his own volition. Having played a leading role in the Young Ireland rebellion of 1848, he had been deported to Van Diemen's Land (now Tasmania) and lived there until he was pardoned in 1854. He was only allowed to return to Ireland in 1856 on the condition that he would not involve himself in politics. ${ }^{27}$

He retained a lively interest in political affairs nonetheless and his itinerary was more that of a political observer than a tourist. While the immediate catalyst for his trip to the continent in 1861 was to come to terms with the recent death of his wife, for the most part he avoided the destinations preferred by those in search of solace. Although he addressed 'readers' directly and thus appears to have intended to publish his journals, he provided little guidance on practical travel matters, only commenting when he encountered problems. ${ }^{28}$ In this sense, his journal is quite different from the travel accounts of Londonderry and Quin in previous decades. Londonderry provided considerable detail about the steamships of the Danube and Quin, a professional writer and author of many articles on travel, included lots of personal observations and humour to entertain the reader. ${ }^{29}$ Whether Smith O'Brien was aware of previous Irish travellers to the region is not known. He made no reference to them or other travellers in his own journals.

These journals were relatively unknown until very recently because, for reasons that are unclear, they were never published. This was a particular pity in the case of Hungary as his journal comes before the flurry of publications sparked by the defeat of Austria in the Austro-Prussian War and the Compromise of $1867 . .^{30}$ In 2013, Richard Davis did historians a service by publishing a survey of Smith O'Brien's extensive travels based on his journals. Katarzyna Gmerek has used the journals to provide a more detailed description of his travels in Poland and Lithuania, especially in terms of his political development and the response of Poles to him. As this article suggests, his entries on eastern Europe also offer an important perspective on western European attitudes generally to the region. ${ }^{31}$

Smith O'Brien's travels can best be seen as a continuation of his political activities. Although the Young Ireland movement collapsed in the wake of the failed rebellion, his travels served to fulfill the demands of its founder, Thomas Davis. In a short piece on 'Foreign Travel' that he wrote in the early 1840 s, Davis extolled travel as a patriotic duty, a means of

26 Smith O'Brien, MS 46, 829/8 (Berlin, 3 June 1863).

27 Kadebo, Ireland and Hungary, op. cit., 25-26.

28 Smith O'Brien, MS 46, 829/8 (Cracow, May 1863).

29 Zarka, 'A dunai gőzhajózás', op. cit., 36, 40.

30 Frank, Picturing Austria-Hungary, op. cit., 97.

31 Richard Davis, Travels of William Smith O'Brien in Europe and the Wider World (Dublin: Geography Publications, 2013); Katarzyna Gmerek, 'William Smith O'Brien in Poland and Lithuania in the 1860s', Polska Irlandia wspólna historia?/ Poland \& Ireland - A Common History?, ed. Krzysztof Marchlewicz, Adam Kucharski (Poznań: Irish Culture Foundation, 2015), 111-23. 
promoting Irish nationalism: "We want the Irish who go abroad to bring something back besides the weary tale of the Louvre and Munich, and the cliffs of the Rhine, and the soft airs of Italy. We have heard of a patriot adventurer who carried a handful of his native soil through the world. We want our friends to carry a purpose for Ireland in their hearts, to study other lands wisely, and to bring back all knowledge for the sustenance and decoration of their dear home." He recommended specifically the following objects of study: the connections between Irish and other Celtic languages, the continental tours of medieval Irish saints, the history of Irish soldiers in foreign armies, but also knowledge of more practical use, such as agricultural and metallurgical practices. ${ }^{32}$

Davis's disciple, Smith O'Brien embraced this mission throughout his travels. $\mathrm{He}$ sought out descendants of seventeenth-century Irish émigrés on the continent. Upon his arrival in Paris in July 1861, for instance, he met with General MacMahon, and in 1863, in the midst of the Polish rebellion, travelled all the way to Grodno, in present-day Belarus, to be introduced to his namesake, O'Brien de Lacy. ${ }^{33}$ Given the limited potential for documenting Ireland's heritage in eastern Europe, however, he focused on the study of issues of direct interest to his Irish contemporaries, such as tithes, the payment of clergy and land ownership. He was not surprised to find commonalities. He had been a leading proponent of the notion of a parallel between Ireland and eastern European nations. Before ever travelling to Poland, he told the British parliament in 1848, in the midst of the devastation of the Irish famine, that the outside world considered British rule in Ireland to be as cruel as that of Russia in Poland. ${ }^{34}$ His trip may have even been an effort to defend the notion of a parallel between Ireland and the nations of Hungary and Poland. Just a few months before his departure for the continent in 1861, he had attracted criticism for appearing to suggest that he, like Wolfe Tone before him, was on a par with Kościuszko, and for presuming to campaign for a pardon from Emperor Franz Joseph for the Hungarian patriot, Count László Teleki. His pitiful record in 1848 certainly did not merit a comparison with Kościuszko. The rebellion consisted of an attack on a group of police barricaded into the home of a widow, Mrs. McCormack, and came to a quick end upon the arrival of police enforcements. ${ }^{35}$ Some nationalists defended him as equal to the Pole, at least in terms of courage and readiness for action, and pointed out that Franz Joseph had indeed granted a pardon to Teleki. Smith O'Brien may have hoped to convince nationalists who were not so sympathetic to his claims. ${ }^{36}$

32 Thomas Davis, Foreign Travel, 208-09, [http://www.ucc.ie/celt/published/E800002-004/index.html, accessed 15 September 2017]

33 Smith O’Brien, MS 32,707 (Paris, 31 July 1861) and MS 46, 829/8 (Berlin, 3 June 1863).

34 Davis, Revolutionary Imperialist, op. cit., 243. The speech was on 10 April 1848.

35 Sloan, William Smith O'Brien, op. cit., $238 \mathrm{ff}$.

36 'The Anti-Irish Press and W. S. O'Brien', The Nation, (12 Jan. 1861). 
Already politically well disposed to Hungary, his encounters with Hungarians confirmed him in his enthusiasm for all things Hungarian. ${ }^{37}$ His commitment to the Irish cause seems to have played an important role. By contrast, in deference to the mainly English readership of $A$ steam voyage down the Danube, his compatriot Quin appears to have deliberately repressed his support for the Hungarian cause. As Zarka has shown, he insisted that the Hungarian elite needed to be educated in western ways before they won self-government, a prerequisite imposed by the British for Ireland too, but held no such reservations in writings in publications aimed at an Irish audience. ${ }^{38}$ British visitors to Hungary writing at the same time as Smith O’Brien were not all so sympathetic to the Hungarians. While Arthur Patterson, an academic who immersed himself in Hungarian life for nearly four years, championed the Hungarian cause, Charles Boner and M. E. Grant Duff, relying more on non-Hungarian sources, were critical. ${ }^{39}$

If even Patterson was doubtful about the progress of "civilisation" in Hungary, declaring the people to "exhibit a curious admixture of former barbarism and intrusive civilisation," Smith O'Brien emphasised that Hungary was the equal of western Europe. ${ }^{40}$ On viewing the ruined castle known as Vishegrad, he declared the scene one to "vie with the most favourite scenes of the Rhine." ${ }^{\text {"41 }}$ His visit to the museum in Pest allowed him to point out the Roman presence in Hungary, an indicator of its western credentials. ${ }^{42}$ As an aristocrat, he had easy entry into the circles of the Hungarian elite and gained Count Béla Széchenyi, son of István, as a personal guide, and through him a meeting with the leader of the passive resistance movement, Ferenc Deák, among others. He noted the fluency of Hungarians in English and French, occasionally even in Latin, and found them as a race "manly" and "gentlemanlike." ${ }^{\star 3} \mathrm{He}$ judged the ladies polished and even the peasant children decently educated. Indeed Hungarians living in the countryside managed to overcome the disadvantage of their situation to reach a level of cultivation equal to the west, according to Smith O'Brien: "Here in this remote district I find in the family circle of Count Augustus at least as much of intellectual culture as I should witness amongst persons enjoying the

37 For an examination of Smith O’Brien's treatment of Hungary specifically, see Róisín Healy, 'Követendő példa Írország számára. William Smith O’Brien ír nemzeti politikus a magyarokról' [Lessons for Ireland: William Smith O'Brien Irish nationalist politician on Hungary, transl. Lili Zach], Idegen szemmel, 15-30. See also Davis, Travels of William Smith O'Brien, op. cit., 170-77.

38 Zarka, 'A dunai gőzhajózás', op. cit., 43-44.

39 Frank, Picturing Austria-Hungary, op. cit., 99-113. The works concerned are Arthur J. Patterson, The Magyars, 2 vols. (London: Smith, Elder and Co., 1869), Charles Boner, Transylvania: Its Products and People (London: Longmans, Green, Reader, and Dyer, 1865), Mountstuart Elphistone Grant Duff, Studies in European Politics (Edinburgh: Edmonston and Douglas, 1866).

40 Quoted in Frank, Picturing Austria-Hungary, op. cit., 127.

41 Smith O’Brien, MS 32,707 (Pest, 15 Aug. 1861).

42 Ibid., (Pest, 16 Aug. 1861).

43 Ibid., (Füred, 19 Aug. 1861). 
greatest advantages in other parts of Europe." His experience with various Catholic priests led him to the conclusion that "the Hungarians have no reason to suppose that their clergy are inferior to the clergy of the other countries of Europe." ${ }^{\prime 4}$ He saw Hungary as a model for Ireland in the question of religious tolerance. Both the Catholics and Protestants of Hungary, lay and clerical, were united in their resistance to Austrian rule, he concluded. ${ }^{45}$ Like Patterson after him, he noted approvingly that there was very little bigotry there, and that the Protestant clergy did not resent the higher revenues enjoyed by the established Catholic church. ${ }^{46}$

Most of all, he was impressed with the courage and ingenuity that the Hungarians had displayed in their political struggle against Austria, qualities that led him to describe them as a "heroic race". He had extensive discussions about the revolution of 1848/49 and concluded that the Austrians had been cowards who were saved only by Russian intervention. Several first-hand accounts of "military execution" - the policy of extracting taxes by means of having soldiers occupy a house-only confirmed his hostility towards Austrian rule. He praised the decision of Hungarian parliamentarians to abstain from the imperial parliament in Vienna and Deák's speech in 1861 condemning the Emperor's dissolution of the newly recalled parliament in Pest. Perhaps mindful of the divisions within Irish nationalism over the extent of self-government desired and the methods to be used to achieve it, he celebrated the unanimity of support for the policy of passive resistance. ${ }^{47} \mathrm{He}$ was very impressed by the show of patriotism at the theatre. When the Austrian national anthem was sung at the German Theatre in Pest, a quarter of the audience refused to stand, but when a Hungarian patriotic song was sung on the stage at the Hungarian Theatre, the audience demanded an encore. ${ }^{48}$

While touring Galicia in 1861, he adopted a more tragic tone, talking about the "unhappy Poles" and the difficulties they faced in being divided between three rulers. But he also drew confidence from the steadfastness of Polish resistance to foreign rule and the current stand-off with the Russian authorities in Warsaw. He felt that the Poles had taken a fundamental step in stopping their servitude: "A freeman may be fettered but he does not become a slave until he acquiesces in his doom." ${ }^{39}$ But, if the Hungarians were the heroes of the 1861 journal, the Poles had replaced them by 1863 because of the intensity of patriotism and unity of cause they demonstrated in the January Uprising against Russian rule. He was hugely impressed by the outward display of hostility to Russia, the women's

44 Ibid., (Hotkocz, 3 Sept. 1861).

45 Ibid., (Füred, 19 Aug. 1861, Graz, 11 Sept. 1861).

46 Frank, Picturing Austria-Hungary, op. cit., 128. Smith O’Brien, MS 32,707 (Füred, 19 Aug. 1861).

47 Smith O’Brien, MS 32,707 (Pest, 23 Aug. 1861).

48 Ibid., (Füred, 19 Aug. 1861).

49 Ibid., (Graz, 11 Sept. 1861). 
adoption of mourning clothes and the men's replacement of their usual hats with caps, and especially their renunciation of festivities: "I know of nothing that history has recorded nothing more sublime than this universal abandonment of social engagements by a people who bewail the fate of their country." He noted the importance of the cohesiveness of the Polish resistance in war. While the Poles could find out the enemy's plans in advance, no spy could penetrate their own ranks, he claimed. ${ }^{50}$

His support for Hungary and Poland was genuine, but British rule in Ireland remained at the centre of his concerns. Throughout his journals he made great efforts to distance himself from British travellers on the continent. He pointed out that he had none of the usual British reserve and turned this to his advantage by eliciting lots of useful information about the places he visited from his fellow-passengers. ${ }^{51} \mathrm{He}$ was disappointed by the Anglophilia he encountered in Hungary and used his travels to educate his hosts about the true nature of British government among his hosts: "I never lose a moment in announcing that I am a Irishman and that Ireland stands in the same position with reference to England as Hungary occupies in relation to Austria." He noted that Hungarians received their information about Ireland from English newspapers, which, he claimed, "falsify every fact and every induction which relates to Ireland." ${ }^{2} \mathrm{He}$ experienced some relief on his departure. Travelling back from Hungary through the Tyrol, he learned that "even the peasants of Tyrol have learnt that the government of England is an oppressor in Ireland." ${ }^{53}$

Clearly critical of Austrian rule, he used his experiences to argue that British rule in Ireland was even worse. When he encountered Slovaks going barefoot, he was reminded of the peasants he was familiar with back home, but decided that it was the "result of choice rather than necessity." And although he had thought the pigs in Ireland were fatter than anywhere, he had to concede that those in Debrecen were even fatter. ${ }^{54} \mathrm{He}$ was impressed that a Hungarian was able to eat his own bacon every day of the year..$^{55}$ In fact, on leaving the Austrian empire in 1861, he concluded that all its territories, even Galicia, were more prosperous than Ireland: "Little as I admire the Austrian government I would willingly exchange the condition of our towns and of our rural districts for the condition of the towns and rural districts through which I have travelled in the Empire of Austria in so far as material prosperity is concerned." ${ }^{56}$ The favourable comparison even extended to the Principality of Wallachia and Moldavia, which he visited two years later. He declared the peasants there "well

\footnotetext{
50 Smith O'Brien, MS 46, 829/8 (Berlin, 3 June 1863).

51 Smith O’Brien, MS 32,707 (Munich, 9 Aug. 1861).

52 Ibid., (Füred, 19 Aug. 1861).

53 Ibid., (Innsbruck, 22 Sept. 1861).

54 Ibid., (Hotkocz, 3 Sept. 1861).

55 Ibid., (Füred, 19 Aug. 1861).

56 Ibid., (Innsbruck, 22 Sept. 1861).
} 
fed" and concluded that "the condition of a Hungarian or Wallachian peasant is enviable when compared with that of an Irish farmer or labourer." ${ }^{.77}$ His visit to Transylvania again confirmed his view that the Irish peasant was uniquely disadvantaged. ${ }^{58}$ Only in the furthest reaches of eastern Europe, in the western gubernii of Russia, which had once formed part of the Polish-Lithuanian Commonwealth, did the peasants approach the poverty of their Irish counterparts, according to Smith O'Brien. ${ }^{59}$

If his venture beyond Poland and Hungary strengthened his argument about the calamitous social and economic consequences of British rule for Ireland, it also required him to confront the reality that other ethnic groups occupied the same territory as the nations so favoured by Irish nationalists and, in some cases, also sought self-government. His journals reveal that he was not willing to consider self-government for any but the so-called historic nations of Poland and Hungary. His travels in 1861 took him to Slovakia and a priest from the region, Fr. Duchon, accompanied him on his journey from Hotkocz to Cracow. Duchon made clear that the Hungarians were just as inclined as the Austrians to force their languages on others and was particularly aggrieved that court proceedings were held exclusively in Magyar. Rather than recommend the use of Slovak or other minority languages, Smith O'Brien expressed regret that Latin was no longer the main language of official communication. ${ }^{60} \mathrm{He}$ also worried lest the aspirations of Romanians in Transylvania to self-government jeopardise those of Hungarians. He warned that the readiness of the Romanians to sit in the Reichsrat in Vienna could undermine the decision taken by the Hungarian Diet of 1861 to reject on principle any assembly that claimed to represent the whole Habsburg Monarchy. ${ }^{61}$

Although Romanians residing to the south and east of Transylvania had already achieved independence with the formation of the principality of Wallachia and Moldavia in 1859, Smith O'Brien was sceptical about their capacity for self-government. Using a typical Orientalist metaphor, he compared the state to an infant, whose development depended entirely on the skills of the government. ${ }^{62}$ "Upon the whole it seems to me that Wallachia is in a state of infancy. It is however a fine fat baby which if well nursed may hereafter become a powerful man." His comments on the Romanians' intelligence suggested, however, that they would be hard pressed to find adequate nurturers from within their ranks. He claimed that they were dark in appearance, but did not look like the Italians and

57 Smith O'Brien, 46, 829/7 (Tour of Romania and Poland, May 1863, Temesovar, 13 May 1863).

58 Smith O’Brien, MS 32, 707 (Cracow, n.d. May 1863).

59 Smith O'Brien, MS 46, 829/8 (Berlin, 3 June 1863).

60 Smith O'Brien, MS 32,707 (Graz, 11 Sept. 1861).

61 Smith O’Brien, MS 46, 829/7 (Temesovar, 13 May 1863).

62 For a similar comment by William Richardson on Russia nearly a century before, see Wolff, Inventing Eastern Europe, op. cit., 84. 
"have not indicated the intellectual qualities which characterise the inhabitants of modern as well as of ancient Italy." He traced back their lack of intelligence to their past experience, perhaps their contact with the Turks. They appeared to him "to be a race whose intelligence has not been developed by favourable circumstances." ${ }^{33}$ Thus, although he avoided any suggestion of hereditary racial weakness, his insistence on the need for "favourable circumstances" and his low opinion of the Romanians' current intellectual state suggested that they were condemned to mediocrity.

The Irish visitor's severest judgment was reserved for the Roma people, whom he encountered in Hungary but realised could be found elsewhere. He claimed that they avoided work and had made theft a "national virtue". ${ }^{44}$ His comments about Jews were more nuanced, but suggest that he was torn between a theoretical commitment to equality and the anti-Semitism that was typical of his contemporaries. ${ }^{65} \mathrm{He}$ did not seek out contact with Jews and expected the worst of them when he did. His first encounter with them was occasioned by the refusal of the horses pulling his carriage to go any further, forcing his party to stop at a "miserable tavern which is kept by a Jew." He was surprised that he actually slept well and that the Jewish owner did not overcharge them. This experience was not, however, enough to change his mind and the Jews he saw in Cracow appeared to confirm his prejudices. He proclaimed that he "did not see a single Jew whose appearance was such as indicates the noble qualities of human nature." The gaze in their eyes he interpreted as meaning: "What can I get from him? Will he buy or sell anything?" While he insisted that he was not prejudiced against "Jews, Mahomedans or Buddhists," he professed himself less surprised at the hostility of Hungarian liberals to Jewish emancipation after his own encounters with Jews. He went on to complain about the Jews' practice of usury, but stopped short of condemning Jews outright. He wrote: "God forbid however that I should impute to the Jews an incapacity for the possession of virtues claimed by Christians." And as if to apologise, he concluded the paragraph with Duchon's claim that "one of the best and most generous men in his parish is a Jew." ${ }^{66}$

While Smith O'Brien managed to maintain his preference for the Polish and Hungarian nations over Slovaks, Romanians, Roma and Jews throughout his travels, he was prepared to soften his opinion of the Hungarians' nemesis, the Austrians. In 1863, before the Compromise was even mooted, he pointed to the concessions made by Austria as evidence of progress. Conscious perhaps of the continued hostility in Westminster to the return of self-government to Ireland, he was particularly critical of the failure by English observers to acknowledge the recent improvement: "A system of government that produces such results

63 Smith O’Brien, MS 46, 829/7 (May 1863).

64 Smith O'Brien, MS 32,707 (Hotkocz, 3 Sept. 1861).

65 For British travellers' views of Roma and Jews, see Frank, Picturing Austria-Hungary, op. cit., 128.

66 Smith O’Brien, MS 32,707 (Cracow, 9 Sept. 1861). 
can scarcely deserve the harsh denunciations which English writers are in the habit of applying to it and now that the principles of constitutional freedom are at least to a certain extent recognised in the parliamentary control of the Reichsrath it is to be hoped that the abuses which belonged to the old system of bureaucratic government will be gradually corrected. ${ }^{67} \mathrm{He}$ also noted approvingly that the government had ceased to issue excessive amounts of money and thus tackled the problem of depreciation that he had noted in $1861{ }^{68} \mathrm{He}$ enthused about the quality of life in Vienna, citing in particular the races at the Prater. His chance encounter with an Irishman serving as an officer in the Austrian army, O'Gorman from County Carlow, whom he found "intelligent" and "gentlemanlike,", could only reinforce his positive assessment of the Austrians. ${ }^{69}$

It was no coincidence that he had reached Cracow by the time he reached his verdict in May 1863. The reports he heard there from Poles, many with wounds from the conflict, about the brutal suppression of the revolt across the border in the Russian partition helped put Austrian rule in perspective. One Polish informant, Władysław Bielski, described how one thousand Russian soldiers surrounded his house, killed four Polish prisoners, and terrorised his ten-year-old daughter with a bayonet. ${ }^{70}$ As Gmerek has pointed out, he named his informant only because the case was already well known beyond Poland and was otherwise coy about his contacts. ${ }^{71}$ His own subsequent experiences with the Russians confirmed the impression created by such reports. If he had resisted motifs typical of western discourse on eastern Europe in his condemnation of Austria in 1861, he embraced them in his discussion of Russia. He complained that: "the ignorant barbarians who form a part of the Russian administration of this country" confiscated books and newspapers that he had collected on his trip, including material written in modern Greek and Irish, when he crossed the border into the Congress Kingdom. To make matters worse, "the barbarians could not read a line of any of the languages in which they were composed." His assessment of Russian soldiers was particularly damning. If war brought out the worst in all men, it caused the Russian to betray "his barbarous origin." He talked freely of atrocities committed by "foreign barbarians." 72

Yet while Russia had replaced Austria as the scourge of eastern Europe in 1863, the Irishman could not help making a case for Britain as its equal. He interpreted the czar's refusal to make concessions to the Poles as a deliberate attempt to provoke the Poles with a view to justifying the transfer of their lands in Lithuania to Russians and saw in it an echo

67 On English criticisms of Austrian government, see Frank, Picturing Austria-Hungary, op. cit., 4.

68 Smith O’Brien, MS 32, 707 (Vienna, 13 Aug. 1861) and MS 46, 829/7 (Cracow, May 1863).

69 Smith O’Brien, MS 46, 829/7 (Cracow, May 1863).

70 Ibid., (Cracow, May 1863). For more details on Smith O’Brien's experiences in Austrian and Russian Poland, see Davis, Travels of William Smith O'Brien, op. cit., 219-25 and Gmerek, 'William Smith O'Brien in Poland and Lithuania in the 1860s', op. cit.

71 Gmerek, 'William Smith O’Brien', op. cit., 118.

72 Smith O’Brien, MS 46, 829/8 (Berlin, 3 June 1863). 
of the "diabolical policy" practiced by the British in confiscating land from the Irish in previous centuries. ${ }^{73}$ Upon his return he delivered a public lecture in Dublin in July 1863 , in which he expressed unreserved support for the Poles. While the bulk of his venom was directed against the Russian government, by extension, the Austrians who supported it, he also managed a swipe at his own immediate enemy, the British. He condemned firstly, Col. Stanton, the British representative in Warsaw, for condoning the conscription policy and repressive methods of the Russians, by extension, the British parliament for failing to back up their sympathy for the Poles with meaningful action. ${ }^{74}$ The lecture was published afterwards and may have riled the Russian authorities so much that they sponsored a counter-publication, Petersburg and Warsaw: Scenes Witnessed during a Residence in Poland and Russia, 1863-64 (London, 1864). The author, an English gentleman, started out as a supporter of Poland but was easily won over to the perspective of the Russians. He may well have been fabricated and given the name, Augustine P. O'Brien, to confuse those looking for Smith O'Brien's account. ${ }^{75}$

The January Uprising provided Smith O'Brien with more than propaganda in his campaign against British rule. It also offered practical lessons in strategy. Since the disastrous 1848 rebellion, he had turned away from violence. Yet faced with Russian atrocities in Poland, he came close to acknowledging that political assassination could be allowed in certain circumstances. He recorded the rebels' view that the execution of those who collaborated with the Russians was an act of justice rather than assassination and that the threat posed by the Russians necessitated such radical steps. In a letter he sent to the Morning News during his travels, he defended the Polish resort to violence unambiguously: "Russian tyranny has been carried to such an extremity that no alternative has been left even to the most cautious and to the most moderate of the Poles." ${ }^{.76}$ The Uprising also caused Smith O'Brien to reconsider the notion of foreign assistance for an Irish rebellion. $\mathrm{He}$ had repeatedly insisted that Irishmen free themselves from reliance on military aid from the French, the usual partner of choice, in opposition to Mitchel, but his response to the January Uprising suggested a mellowing of this position. He concluded his public lecture with a call for Irishmen to join France to fight for the Poles. If Irishmen were to fight with France for Poland, he could hardly object to them fighting with France for Ireland. In the end, however, he concluded that linguistic difficulties made Irish brigades in Poland a rather improbable prospect and opted for a collection of money instead..$^{77}$

73 Ibid., (Berlin, 3 June 1863).

74 Davis, Revolutionary Imperialist, op. cit., 359. William Smith O'Brien, Lecture on Poland (Dublin: Goodwin, Smith and Netherscott, 1863), 9, 21.

75 Brian Earls, 'By reason of past history', Dublin Review of Books 8 (Winter, 2008), [http://www.drb.ie/ more_details/08-12-08/By_Reason_of_Past_History.aspx, accessed].

76 Morning News (18 June 1863).

77 Davis, Revolutionary Imperialist, op. cit., 359. Smith O'Brien, Lecture on Poland, op. cit., 24. 
Smith O'Brien did not live to develop his thoughts on the role of violence and foreign aid in the Irish nationalist struggle, as he died the following year, in 1864. His observations on Hungary and Poland, at least those that he made public, did provide an important legacy to Irish nationalism, however. The fact that a failed rebel approved of the January Uprising helped legitimise violence as a means of political action. The radical organisation founded in 1858, the Irish Republican Brotherhood or Fenians, drew inspiration from the Uprising and one member even rechristened Ireland "Poland of the Sea" at a rally in November $18633^{78}$ Only four years later it instigated its own rebellion against British rule. The same organisation, relaunched after the turn of the twentieth century, was responsible for the 1916 Rising which eventually led a majority of Irish subjects to support complete separation from Britain in the election of 1918.

Smith O'Brien's claim of a parallel with Hungary was probably even more significant in this context. He made the case for following Hungary's policy of passive resistance in articles in the popular nationalist paper, the Freeman's Journal, and these may have been one of the sources for an influential book which appeared in 1904. Written by Arthur Griffith, founder of Sinn Féin, it took its title, Ireland and Hungary: A Parallel, from an article of Smith O'Brien's and formed the blueprint for the policy of abstention from Westminster that was practiced from 1918 and prefigured the arrival of legislative independence in 1922. ${ }^{79}$ Thus, far from confirming the superiority of western Europe, the travels of Smith O'Brien helped to challenge it and bring about the disintegration of one of its pillars, the United Kingdom. The break-up of the Habsburg Monarchy and the establishment of independent states in Poland, Hungary and elsewhere at precisely the same juncture ensured the continued plausibility and popularity of an eastern European parallel with Ireland, at least until the destructive events of the 1930s and 1940s.

\section{BIBLIOGRAPHY}

A report of the debate in the House of Commons of Ireland, on Tues. and Wed., $22^{\text {nd }}$ and $23^{\text {rd }}$ Jan. 1799 on the subject of an union (Dublin, 1799).

Berber Neval. 'The Irish Paradigm in the $19^{\text {th }}$ Century British Discourse on Bosnia-Herzegovina', Imagining Frontiers: Contesting Identities, ed. Steven Ellis, Ludá Klusákova (Pisa: Pisa U.P., 2007).

Boner Charles, Transylvania: Its Products and People (London: Longmans, Green, Reader, and Dyer, 1865).

Creagh James, Over the borders of Christendom and Eslamiah: A Journey through Hungary, Slavonia, Serbia, Bosnia, Herzegovina, Dalmatia, and Montenegro, to the North of Albania in the Summer of 1875 (London: Tinsley, 1876).

The Irish People (5 Dec. 1863). I am indebted to Mary Harris for this reference.

79 Kadebo, Ireland and Hungary, op. cit., 33-41. 
Davis Richard, Revolutionary Imperialist: William Smith O'Brien, 1803-1864 (Dublin: Lilliput, 1998).

Davis Richard, Travels of William Smith O'Brien in Europe and the Wider World (Dublin: Geography Publications, 2013).

Davis Thomas, Foreign Travel. For digital version, see http://www.ucc.ie/celt/published/ E800002-004/index.html.

Earls Brian, 'By Reason of Past History', Dublin Review of Books 8 (Winter, 2008), [http://www. drb.ie/more_details/08-12-08/By_Reason_of_Past_History.aspx].

Gmerek Katarzyna, 'William Smith O'Brien in Poland and Lithuania in the 1860s', Polska Irlandia wspólna historia?/ Poland \& Ireland - A Common History?, ed. Krzysztof Marchlewicz, Adam Kucharski (Poznań: Irish Culture Foundation, 2015), 111-23.

Elliott Marianne, Wolfe Tone: Prophet of Irish Independence (New Haven: Yale U.P., 1989).

Foley Michael, 'John David Bourchier: an Irish Journalist in the Balkans', Irish Communications Review, 10/1 (2007), https://doi.org/10.21427/D7CM63.

Frank Tibor, Picturing Austria-Hungary: the British Perception of the Habsburg Monarchy 1865-1870 (Boulder, Col.: Social Science Monographs, 2005).

Freeman's Journal.

Grant Duff, Mountstuart Elphistone, Studies in European Politics (Edinburgh: Edmonston and Douglas, 1866).

Healy Róisín, 'Inventing Eastern Europe in Ireland, 1848-1918', The Yearbook of the "Gheorghe Şincai" Institute for Social Sciences and the Humanities of the Romanian Academy, XII (2009), 103-17, [http://www.icsumures.acad-cluj.ro/anuare/abstracts\%202009.pdf].

Healy Róisín, 'Követendő példa Írország számára. William Smith O’Brien ír nemzeti politikus a magyarokról', Idegen szemmel. Magyarságkép 19.-20. századi útlírásokban, ed. Árpád Hornyák, Vitári Zsolt (Budapest: Szerkesztők, 2010), 15-30.

Healy Róisín, Poland in the Irish Nationalist Imagination, 1772-1922: Anti-Colonialism within Europe (London: Palgrave, 2017).

Kadebo Thomas, Ireland and Hungary: A Study in Parallels with an Arthur Griffith Bibliography (Dublin: Four Courts Press, 2001).

McLean Thomas, The Other East and Nineteenth-Century British Literature: Imagining Poland and the Russian Empire (London: Palgrave, 2012).

MacWhite Eoin, 'Thomas Moore and Poland', Proceedings of the Royal Irish Academy 72 (Dublin: Royal Irish Academy, 1972).

Merchant John A., 'The Impact of Irish-Ireland on Young Poland, 1890-1919', Eastern European Monographs (Boulder: Columbia U.P., 2008).

Mickiewicz Adam, Leabhar na Pólainne, transl. Liam Ó Rinn (Dublin: An Comhlucht Éireannach um Thráchtáil Eadarnáisiúnta, 1922).

Mitchel John, Jail Journal or Five Years in British Prisons (New York: The 'Citizen', 1854).

Molyneux Capel, A reply to the memoire of Theobald McKenna, Esq. On some questions touching the projected union of Great Britain and Ireland (Dublin: H. Fitzpatrick, 1799).

Morning News.

O'Reilly William, Penz Andrea, Freiheit und Unabhängigkeit als imperative Postulate: Nationale Bewgung in Irland und Ungarn im Vergleich (1780-1870) (Graz: Leykam Verlag, 2006).

Patterson Arthur J., The Magyars, 2 vols (London: Smith, Elder and Co., 1869).

Quin Michael Joseph, A steam voyage down the Danube: with Sketches of Hungary, Wallachia, Servia and Turkey (London, 1835). 
Sloan Robert, William Smith O'Brien and the Young Ireland Rebellion of 1848 (Dublin, Four Courts Press, 2000).

Smith O'Brien William, Journal of an Excursion made during the months of August and September 1861 (National Library of Ireland, MS 32,707).

Smith O'Brien William, Journal, Berlin, June 1863 (National Library of Ireland, MS 46 829/8).

Smith O'Brien William, Lecture on Poland (Dublin: Goodwin, Smith and Netherscott, 1863).

Smith O'Brien William, Tour of Romania and Poland (National Library of Ireland, MS 46, 829/7).

Spenser Edmund, A View of the Present State of Ireland (1596). For digital version, see https://celt. ucc.ie//published/E500000-001/.

Taylor, Alan John Percivale, The Troublemakers: Dissent over Foreign Policy 1792-1939. $2^{\text {nd }}$ ed. (London: Pimlico, 1993).

The Irish People.

The Nation.

Todorova Maria, Imagining the Balkans (Oxford: Oxford U.P., 1997).

Touhill Blanche M., William Smith O'Brien and his Irish revolutionary companions in penal exile (Columbia: Univ. of Missouri Press, 1981).

Wolff Larry, Inventing Eastern Europe: The Map of Civilization on the Mind of the Enlightenment (Stanford: Stanford U.P., 1994).

Vane Charles William Stuart, Marquess of Londonderry, A steam voyage to Constantinople by the Rhine and the Danube in 1840-41 (London: 1842).

Zarka Zsuzsanna, 'A dunai gőzhajózás, mint a fejlődés motorja. Ír benyomások a Habsburg Birodalomról és Magyarországról a 19. század kőzepén', In Idegen szemmel. Magyarságkép 19.-20. századi útlírásokban, ed. Árpád Hornyák, Vitári Zsolt (Budapest: Szerkesztők, 2010), 31-49. 